\title{
Training participation of internationalized firms: establishment-level evidence for Switzerland
}

Samuel Muehlemann ${ }^{1,2}$

\section{Correspondence: \\ samuel.muehlemann@vwi.unibe.ch ${ }^{1}$ University of Bern, Department of Economics, Bern, Switzerland \\ IZA Bonn, Bonn, Germany}

\begin{abstract}
Background: Switzerland is host to many international companies, and a large share of Swiss firms is exporting goods and services abroad. While the vocational education and training (VET) system in Switzerland has a long tradition, there is a paucity of studies investigating the effects of the ongoing internationalization on the training participation of internationalized firms.

Methods: The empirical analysis uses representative cross-sectional survey data for Switzerland to estimate a firm's training decision in 2009. I apply multivariate regression techniques to account for observable differences between domestic and internationalized firms.

Results: The results show that small and internationalized firms with less than 50 employees have a significantly lower training probability than comparable domestic firms, while this is not the case for larger firms - mainly because internationalized firms are too specialized and provide internal training to workers without a VET degree. Relating the results to the theory of the varieties of capitalism, I find no statistically significant differences in the training participation of similar-sized firms with headquarters in typical liberal market economies (United States, United Kingdom) and a coordinated market economy (Germany), stressing the importance of other factors such as location, sector, firm size, and the local labor market environment.

Conclusion: While large internationalized firms show a similar training participation as domestic firms, a large fraction of small and internationalized firms does not offer apprenticeships even though they are aware of a potentially suitable training occupation. Thus policies promoting alternative forms of training, such as training networks that facilitate access to apprenticeship training for small and specialized firms, may possibly increase the future training participation of internationalized firms.

JEL-codes: J24; M51; M53

Keywords: Internationalization; Globalization; Multinational enterprises; Firm training; Apprenticeship training; Vocational training; Varieties of capitalism
\end{abstract}

\section{Background}

Labor market-oriented education (i.e., vocational and professional education and training) in Switzerland is seen as an important competitive advantage by companies, experts and the general public (BBT 2011, MIS Trend 2008). Switzerland is host of many international enterprises and has an important export industry, so that many firms regularly interact with foreign firms or customers. However, thus far there is a paucity of studies on potential 
effects of the ongoing internationalization on a firm's recruitment and training behavior, also because of a lack of appropriate data (Eriksson 2010).

There are several reasons why internationalized firms may show a different recruitment and training behavior than domestic firms. Human resources (HR) and training strategies may directly be influenced by a firm's headquarters or owners, or indirectly through the appointment of management. Thus while apprenticeship training is a familiar and well-recognized educational path in countries such as Switzerland and Germany, management from other countries may be unfamiliar with that type of training, and consequently implement other recruitment strategies.

To analyze the effects of the ongoing internationalization, I use establishment-level administrative survey data on apprenticeship training in Switzerland in 2009. I define an internationalized firm as either being a subsidiary of a company with headquarters abroad, owned by foreign nationals, or predominantly export-oriented. For small firms with less than 50 employees, I find that internationalized firms are significantly less likely to train apprentices, while this is not the case for large firms. Moreover, internationalized firms with a high share of workers without a high school, vocational or professional education and training, or university degree are less likely to participate in training than domestic firms.

The remainder of the paper is structured as follows: Section "Theory, empirical literature and hypotheses" discusses the relevant theoretical and empirical literature and derives testable hypotheses. Section "Data and bivariate analysis" describes the data and provides descriptive statistics. Section "Method, results and discussion" presents a multivariate analysis of a firm's training participation. Section "Conclusion" concludes.

\section{Theory, empirical literature and hypotheses}

This section discusses the relevant literature regarding the potential effects of the internationalization on a firm's straining behavior. Based on the discussion of the existing theoretical and empirical literature, I subsequently derive testable hypotheses.

Human capital theory (Becker 1962) provides a basic framework regarding the provision of human capital at the workplace. While firms will never make a net investment in general skills when labor markets are competitive, there is an incentive for firm-provided training for the case of firm-specific human capital or when labor markets are imperfect ${ }^{\mathrm{a}}$. However, a key question for multinational enterprises is whether to transfer HR practices to subsidiaries in other countries, or to adapt local practices and the local labor market environment. Regarding vocational education and training, there are three broad and relevant approaches (cf. Edwards 2011).

First, the country-of-origin approach proposes that the culture at a corporation's headquarters strongly influences decisions in all subsidiaries. A main potential factor that can contribute to such a transfer is the composition of members of the board in regard to their nationality. While lower and middle management are often recruited locally, the members of the board of a multinational enterprise (MNE) are predominantly nationals from the MNE's country of origin. However, the extent of much such effects that are related to the country of origin depends strongly on the degree of a subsidiary's autonomy. Dickmann (2003) finds that German subsidiaries in Spain and Portugal train fewer apprentices if local HR managers have more autonomy compared to those where 
decisions are predominantly made in Germany. Similarly, such effects can also be expected for the case where foreign investors take direct influence on a firm's HR practices. However, even if subsidiaries strongly depend on headquarters, they may still decide to engage in certain socially desirable activity - even if not legally required in order to gain support from local communities (Kostova et al. 2008) or to signal good working conditions (Backes-Gellner and Tuor 2010). One such example of a socially desirable activity may be the provision of apprenticeship training places.

The existence of country-of-origin effects may depend on different institutions, as discussed in the literature on the "varieties of capitalism" (e.g., Hall and Soskice 2001, Busemeyer and Trampusch 2012). Hall and Soskice (2001) distinguish two main types of market economies: liberal and coordinated market economies. An insufficient coordination between employers and institutions in liberal market economies (with the United States as the extreme type) is likely to lead to a school-based education system in combination with only firm-specific on-the-job training and a "hire-and-fire" mentality Morton and Siebert (2001). Conversely, a coordinated market economy (with Germany as the extreme type) typically features a vocational education and training system that goes beyond mere on-the-job training, since apprentices graduate with a nationally recognized educational degree. The reason why firms are willing to invest in such training is attributed to the ability of firms to plan for a longer time horizon. As a result, depending on whether headquarters are predominantly from a country with a liberal (coordinated) market economy, a corresponding subsidiary would be less (more) likely to engage in apprenticeship training.

Analyzing the location of headquarters on a subsidiary's training decision, Beck et al. (2009) find empirical evidence for country-of-origin effects based on cross-sectional data from the Cranet project in 2000. In addition, several empirical studies for Switzerland find a lower participation rate of foreign firms in apprenticeship training, yet these studies are unable to shed light on the reasons for the lower observed training participation (Muehlemann et al. 2007a, b; Muehlemann and Wolter 2007; Schweri and Müller 2008; Wolter et al. 2006). In addition, Schweri and Müller (2008) show that a firm's the degree of internationalization (defined by foreign ownership, foreign investors, and the import and export shares) not only decreases the probability of training, but also the training intensity. For Germany, Schmitt and Sadowski (2003) find that U.S. subsidiaries have a lower training intensity than domestic firms. Looking at general differences in human resource management practices, Björkman et al. (2007) and Gooderham et al. (1998) find statistically significant differences for subsidiaries of MNE's in a number of countries.

Second, the host-country approach proposes that a firm adapts to the local environment, implying that the headquarters' influence on subsidiaries abroad is limited, or that subsidiaries are sufficiently autonomous to make their own decisions, so that no differences between internationalized and domestic firms remain. Thus the organization of a host countries education and training system has a direct impact on whether a subsidiary will engage in labor market-oriented education (cf. Blossfeld et al. 2008, Marsden 1999).

Host-country effects may be more pronounced if those responsible for a firm's recruitment and training strategies are recruited locally. Thus a firm operating in a country with an extensive vocational/professional education and training (VET/PET) system may be more likely to hire employees that have a VET or a PET degree, or hire employees who are at least familiar with the local education system ${ }^{\mathrm{b}}$. There are several empirical studies 
that find evidence for host-country effects, i.e., HR strategies of subsidiaries adapt to local practices e.g., (Rosenthal and Nohria 1994).

Third, the dominance approach proposes that the globalization process leads to a best practice that is adopted by all firms. Consequently, no observed differences between foreign and domestic firms would remain. Pudelko and Harzing (2008) find empirical evidence for dominance effects in German, Japanese and U.S. subsidiaries, where all firms converge towards U.S. HR practices. However, such processes clearly depend on dynamic effects and may change over time. Thus, data requirements to identify such effects are rather high, which is a main reason why there is a still a paucity of studies investigating such effects. Nonetheless, while there may have been a convergence in many countries towards a school-based education system with the aim to increase the enrollment rates in the university system, the recent financial crisis with its severe consequences for youth unemployment in many industrial countries may have been a turning point towards policies that encourage VET in many European countries, but also in the United States (cf. Biavaschi et al. 2012, Eichhorst et al. 2012, Holzer 2012, Lerman 2013).

Summing up, the literature is ambiguous on how internationalization influences a firm's training behavior. Thus identifying the effects of internationalization on a firm's training is an empirical question.

Due to data limitations, I can solely test whether internationalized firms have a lower training probability than domestic firms (i.e., whether there are country-of-origin effects), but in case there are no observed differences in the training participation, I cannot test whether that is due to host-country effects or dominance effects.

Hypothesis 1: Internationalized firms have lower higher training probability than domestic firms.

However, as I observe the location of headquarters, I can additionally test whether subsidiaries of enterprises with headquarters from liberal market economies differ in their training participation from those with headquarters in coordinated market economies.

Hypothesis 2: Subsidiaries of multinational enterprises with headquarters in a liberal market economy have a lower training probability than subsidiaries of multinational enterprises with headquarters in coordinated market economy.

The next section provides information about the survey and provides a bivariate analysis. A multivariate analysis of a firm's training participation is provided in Section "Method, results and discussion".

\section{Data and bivariate analysis}

I use data from a Swiss cross-sectional survey on apprenticeship training in 2009 (Strupler and Wolter 2012). The survey was conducted at the establishment level and is representative for the population of Swiss firms ${ }^{c}$. Internationalized firms are defined as follows: First, subsidiaries that are part of a company with headquarters abroad; second, firms that are predominantly foreign-owned; and third, firms that are primarily exporting their goods and services to firms located abroad. A firm is hereafter defined as internationalized if any of the three criteria above apply ${ }^{\mathrm{d}}$. 
The share of internationalized firms in Switzerland remained relatively stable since 2000, fluctuating between $11 \%$ und $12 \%$. In 2009 , 3.3\% of internationalized firms belong to a company with headquarters abroad, $8.6 \%$ are predominantly foreign-owned, and $2.9 \%$ are primarily exporting their goods and services to firms located abroad. Concerning a firm's training participation, I follow Strupler and Wolter (2012) and exclude establishments that train in unofficial occupations at the upper secondary or the tertiary level, establishments that are not an independent subsidiary of another company, or highly specialized subsidiaries that are part of a company that already trains apprentices. Following this definition, about $78 \%$ of internationalized and $83 \%$ of domestic firms with more than two employees can potentially train apprentices.

In 2009 , the average training probability of an internationalized firm was $27 \%$, a substantially lower value compared to a domestic firm (44\%). Thus based on the bivariate analysis I find support for hypothesis 1 . However, looking at different firm size categories, it is apparent that this difference is largely attributed to small internationalized firms with fewer than 50 employees, as the training participation of large internationalized firms with more than 100 employees even exceeds that for domestic firms (Table 1) ${ }^{\mathrm{e}}$. Looking at differences between language regions the results are very similar among small firms, i.e., the training participation of internationalized firms is lower than in domestic firms, except for large firms with hundred and more employees in the French and Italian speaking part of Switzerland.

Furthermore, I investigate the training participation in 2009 for firms that belong to a company with headquarters abroad. Thus this analysis is restricted to a subgroup of internationalized firms, as the nationality of firm ownership for those firms that are not foreign subsidiaries is unknown. The classification of headquarter regions is based on the theory of "varieties of capitalism" (Hall and Soskice 2001). As a simplifying assumption, these authors distinguish between liberal market economies (LME) and coordinated market economies (CME), where the United States (and to some extent the United Kingdom) are the extreme type of a LME. However, also countries like Canada, Ireland, Australia and New Zealand are typically classified as LMEs. Conversely, Germany is classified as the extreme form of a CME, together with countries such as Austria, Sweden, Norway, Finland, The Netherlands, Belgium, Japan, and Switzerland. However, Hall and Gingerich (2009) treat Switzerland and Japan as special cases, because Switzerland features many liberal aspects of a market economy, particularly regarding the low employment protection legislation in the Swiss labor market. While small German firms have a significantly lower training participation rate than domestic firms, large German firms even have a higher training participation rate than domestic firms (Table 2).

These results suggest that the country-of-origin of a subsidiary (i.e., the location of its headquarters) is not the main determinant of a firm's training decision, providing evidence

Table 1 Training participation by firm size (2009)

\begin{tabular}{|c|c|c|c|c|c|c|c|}
\hline & \multicolumn{2}{|c|}{$\begin{array}{l}\text { German-speaking } \\
\text { part of Switzerland }\end{array}$} & \multicolumn{2}{|c|}{$\begin{array}{l}\text { French \& Italian speaking } \\
\text { part of Switzerland }\end{array}$} & \multicolumn{2}{|c|}{ All firms in Switzerland } & \multirow[b]{2}{*}{ Obs. } \\
\hline & Inter-nationalized & Domestic & Inter-nationalized & Domestic & Inter-nationalized & Domestic & \\
\hline 1-9 empl. & $10 \%$ & $36 \%$ & $9 \%$ & $30 \%$ & $10 \%$ & $34 \%$ & 4374 \\
\hline 10-49 empl. & $32 \%$ & $58 \%$ & $16 \%$ & $53 \%$ & $26 \%$ & $56 \%$ & 2017 \\
\hline 50-99 empl. & $62 \%$ & $68 \%$ & $50 \%$ & $65 \%$ & $58 \%$ & $67 \%$ & 855 \\
\hline 100+ empl. & $92 \%$ & $74 \%$ & $79 \%$ & $90 \%$ & $89 \%$ & $77 \%$ & 969 \\
\hline
\end{tabular}


Table 2 Training participation by liberal and coordinated market economies

\begin{tabular}{lllll}
\hline Location of headquarters & $<\mathbf{5 0}$ employees & Obs. & $\mathbf{5 0 +}$ employees & Obs. \\
\hline Switzerland & 0.39 & 5957 & 0.73 & 1583 \\
Germany (CME) & 0.08 & 48 & 0.89 & 50 \\
US, UK (LME) & 0.03 & 33 & 0.70 & 49 \\
\hline
\end{tabular}

against hypothesis $2^{\mathrm{f}}$. In addition, because the training probability of small internationalized firms is very low, it is also of interest to investigate the qualitative responses of non-training firms concerning the importance of various reasons why they do not offer apprenticeship training.

Table 3 shows statistically significant differences (at the 5\%-level) between internationalized and domestic firms in the subjective assessment of the importance of various reasons for a firm not to participate in apprenticeship training in 2009. The two most important reasons against providing apprenticeship training for small internationalized firms (compared to domestic firms) are a high degree of specialization (43.5\%) and the provision of internal qualification and training to employees without a VET degree (44.9\%). Moreover, internationalized firms are more likely to state that they currently have no need for skilled workers or that they find it cheaper to recruit from the external labor market. However, only $16.4 \%$ of small internationalized firms state that an important reason for not offering apprenticeships is that they are unaware of a suitable training occupation. In other words, the vast majority of small internationalized nontraining firms could potentially offer apprenticeships in an official training occupation, but predominantly refrains from doing so - and to a larger extent than domestic firms because they are too specialized and (possibly as a consequence thereof) provide internal training to employees without a vocational degree.

Descriptive statistics on the variables used in the multivariate analysis in the next section are provided in Additional file 1: Table SA.1

\section{Method, results and discussion}

In this section I analyze a firm's training participation in a multivariate setting. In the absence of panel data, the training participation of internationalized firms cannot be analyzed over time at the establishment level. Ideally, we would like to observe a change in firm ownership (from domestic to foreign, or vice versa) and then test for

Table 3 Reasons for not offer apprenticeship training (firms with $<50$ employees)

\begin{tabular}{llc}
\hline $\begin{array}{l}\text { Reason for not offering apprenticeship training } \\
\text { ( } \mathbf{l} \text { very } \text { important/important, } \mathbf{0}=\text { else) }\end{array}$ & $\begin{array}{l}\text { Internationalized } \\
\text { firm }\end{array}$ & $\begin{array}{l}\text { Domestic } \\
\text { firm }\end{array}$ \\
\hline $\begin{array}{l}\text { Firm is too specialized to offer training for an entire } \\
\text { apprenticeship program }\end{array}$ & $43.5 \%$ & $36.6 \%$ \\
$\begin{array}{l}\text { Demand for skilled labor is satisfied through internal } \\
\text { qualification and training of personnel without a VET degree } \\
\text { Currently no need for skilled labor }\end{array}$ & $44.9 \%$ & $37.8 \%$ \\
Cheaper to recruit skilled workers on external labor market & $28.3 \%$ & $20.9 \%$ \\
No suitable training occupation & $16.4 \%$ & $17.8 \%$ \\
Graduates apprentices frequently leave the firm after training & $18.8 \%$ & $12.3 \%$ \\
\hline
\end{tabular}

Notes: $\mathrm{N}=5191$. 
any effects that such an event would have on a firm's future training participation, or similarly the effects of a significant increase in a firm's export share. Thus, when estimating the coefficient on the variable "internationalized firm" on the training participation based on cross-sectional data, the results may be affected by unobserved effects between domestic and internationalized firms that are not directly related to the applied measure of internationalization, but correlate with a firm's training participation (e.g., the degree of specialization, or the characteristics of a firm's products or services) ${ }^{g}$.

Firms may not only train apprentices for the purpose of retaining them as skilled workers, but rather for production-oriented reasons. Thus I will also account for the importance of a firm's various recruitment strategies, as well as the labor market environment (as a measure of how difficult it is to find suitable skilled workers on the external labor market). As the training participation differs rather strongly between small and large firms, I present the results separately for firms with more (less) than 50 employees.

Even when controlling for the qualification structure of the workforce, regional effects, firm size and the sectoral affiliation, small internationalized firms have an almost 18\%-point lower training probability than domestic firms (Additional file 1: Table SA.2, model 4). External recruitment of experienced skilled workers, the internal qualification and training of employees without a vocational degree, hiring graduates from full time school-based education programs and public training workshop, and hiring university dropouts are all substitutes to providing own apprenticeships. However, the magnitudes of the effects do not differ significantly between domestic and internationalized firms (Additional file 1: Table SA.2, model 6) ${ }^{\mathrm{h}}$. However, while the share of employees with a VET or high school degree strongly increases the training participation of small domestic firms (i.e., a 10\%-point increase in the share of employees with a VET/high school degree increases the training probability by about 3\%-points), I find a much smaller corresponding effect for internationalized firms, as indicated by the statistically significant interaction term (Additional file 1: Table SA.3, models 5 and 6). A similar result can be found for the share of employees with other forms of education. Thus small internationalized firms with a high share of employees without a degree at the upper secondary or tertiary level are less likely to provide apprenticeship training compared to otherwise comparable domestic firms. This result is in line with the qualitative responses of non-training firms in Table 3, i.e., that an important reason for small internationalized firms not to provide apprenticeships is that these firms are too specialized to provide an entire apprenticeship program and prefer the qualification and training of employees without a vocational degree. Thus the results imply that small internationalized firm may opt to train only the necessary firm-specific skills that are required to carry out corresponding tasks in the firm's production process, but have a lesser need that the employees also acquire a substantial amount of general skills to complement a firm's specific skill requirements.

Large and internationalized firms with more than 50 employees have an 8.5\%-points lower training probability compared to domestic firms when controlling for sector, cantons and recruitment strategies (Additional file 1: Table SA.3, model 1). However, that difference is no longer statistically significant when including controls for a firm's qualification structure, labor market environment, and interaction terms (models 4-6). For large firms, only hiring foreign skilled workers and university substitutes are substitutes for training own apprentices, as all other recruitment strategies are not significantly associated a firm's training decision. Moreover, I find a strongly negative and statistically 
significant association between the share employees with a university degree and the training provision. A 1\%-point increase in the share of university graduates reduces the firm's training probability by more than $0.5 \%$-points, whereas the strong and positive association between the share of VET and high school graduates and a firm's training provision remains similar than for small firms. However, unlike for small firms, I find no significant differences between internationalized and domestic firms in regard to the effects of the qualification structure of a firm's workforce on a firm's training provision.

A firm's labor market environment significantly influences the training participation of small firms, but not for large firms (Additional file 1: Table SA.2 and A.3). While small domestic firms with difficulties to find skilled labor on the external labor market increase their training probability by $25 \%$-points, I also find a statistically significant effect for small internationalized firms (+7\%-points). Relating the size of the coefficients to the average training participation of either group, the magnitude of these effects is striking: both small internationalized and domestic firms almost double their probability to offer apprenticeships when facing difficulties in finding skilled workers on the external labor market.

While the data that I use for this paper provides new evidence to explain the training behavior of internationalized firms, future research should analyze the training behavior of internationalized firms in a dynamic setting (e.g., to identify the effects of a takeover by foreign investors), and include more information about the organizational structure of a firm (e.g., the nationality and educational background of the management responsible for implementing HR and training strategies, or the degree of autonomy for foreign subsidiaries).

Finally, the results for Switzerland may be not necessarily apply to other countries. Switzerland is a small open economy with an important export-sector, and a large majority of internationalized firms are export-oriented. Thus in countries with a larger domestic market, internationalized firms could potentially show a different training behavior. Similarly, there are differences in institutions and policies across countries (e.g., Brockmann et al. 2008) that could also affect the training behavior of internationalized firms. Nonetheless, as Switzerland is a country with relatively few labor market regulations and firms have considerable freedom regarding their training behavior, the evidence that internationalized firms behave to a large extent similarly than domestic firms may be of interest to other countries with a VET system, as well as for countries that may want to introduce a VET system in the future.

\section{Conclusion}

This paper adds to the literature by acknowledging that internationalized firms are not randomly located across regions and sectors. While theoretical predictions about the training and recruitment behavior of internationalized firms are ambiguous, descriptive statistics show that small internationalized firms with less than 50 employees are significantly less likely to offer apprenticeship training than domestic firms. A multivariate analysis reveals that this difference mainly arises because small internationalized firms with a high share of employees with a vocational degree are less likely to offer apprenticeships. Qualitative responses of non-training firms show that small internationalized firms, compared to domestic firms, are typically too specialized to provide an entire apprenticeship program and instead provide internal training to employees without a VET degree. However, more than $80 \%$ of non-training firms state they are aware of a potentially suitable training occupation, indicating that many internationalized firms currently 
not offering apprenticeships could potentially provide training places. While the share of non-traditional forms of training (such as training networks) in Switzerland increased in recent years, particularly by facilitating the training participation for small firms, policies promoting training networks directly targeted at small internationalized firms could potentially increase their future training participation.

Moreover, the labor market environment shows a strong association with a firm's willingness to train apprentices. The probability to train apprentices is almost twice as high for small firms (both internationalized and domestic) that have difficulties to find suitable skilled workers on the external labor market.

Subsidiaries of firms with headquarters abroad generally show a lower training participation, which can be interpreted as country-of-origin effects. However, such effects are less important compared to firm size, regional factors and a firm's sector affiliation. While German subsidiaries are on average more likely to train apprentices than US and UK subsidiaries (as predicted by the theory of the varieties of capitalism, cf. Hall and Soskice 2001), that difference in training participation is no longer statistically significant when controlling for firm size and sector affiliation.

\section{Endnotes}

${ }^{a}$ Leuven (2005) provides a survey of this literature and Wolter and Ryan (2011) discuss the relevance of human capital theory to apprenticeship training.

${ }^{\mathrm{b}}$ In Switzerland, a VET degree correpsonds to a completed apprenticeship program at the upper secondary level (ISCED 3), whereas a PET degree corresponds to a degree at the tertiary level (ISCED 5B).

${ }^{c}$ However, the agricultural sector and all firms with 2 or less employees were excluded. Detailed descriptive statistics by sector are available upon request.

${ }^{\mathrm{d}} \mathrm{I}$ also conducted my analysis using an alternative definition of internationalization that only includes the first two criteria. However, the results remain qualitatively similar. This finding can be explained by the fact that foreign-owned firms and subsidiaries that belong to headquarters abroad are also predominantly export-oriented.

e Previous studies that are not directly focused on the effects of internationalization typically assume a constant effect of foreign firms on the training participation (Wolter et al. 2006, Muehlemann et al. 2007b, Schweri and Müller 2008). However, Kluike (2012) analyses 33 US subsidiaries in Switzerland and finds a training participation rate of $52 \%$, which is substantially above the training participation rate in Switzerland (even for domestic firms), most likely because she analyses larger firms that on average employ more than 300 employees. However, in line with the present results, she also finds that the training participation increases significantly with firm size.

${ }^{\mathrm{f}}$ Moreover, the training participation of German subsidiaries, conditional on firm size and industry sector, does not statistically differ from the training participation of US and UK subsidiaries, thereby rejecting hypothesis 2. For reasons of space, these results will not be reported in Section "Method, results and discussion".

${ }^{\mathrm{g}}$ Nonetheless, I can analyze the training participation for a small non-random group of firms that are observed in 2009 but also in the 2004 survey. The results show that from a total of 21 firms that were classified as domestic in 2004 and internationalized in 2009, only a single firm withdrew from apprenticeship training after being internationalized. Conversely, the training participation remained unchanged for 19 out of 25 firms that were 
classified as internationalized in 2004 but domestic in 2009. From the 6 firms that incurred a change in status, there were 3 firms that started to train apprentices and 3 firms that withdrew from training apprentices. Thus these results suggest that the internationalization of firms does not appear to have strong effects on a firm's training participation. However, the firms that could be observed over time are larger in size than an average firm, thus these results may be seen as complementary to the cross-sectional analysis of large firms (where descriptive statistics show no differences in the training participation among domestic and internationalized firms) and not used as evidence against the observed lower training probability of small internationalized firms. Thus representative panel data would be needed to identify a causal effect of the internationalization on the training participation of small firms.

${ }^{\mathrm{h}}$ Interaction terms for recruitment strategies and a dummy variable for the status of internationalization are not reported for reasons of space.

${ }^{\mathrm{i}}$ I also find that firms with difficulties to find skilled workers are more likely to recruit apprenticeship graduates from other firms (poaching), however, to a larger degree for domestic than for internationalized firms. Firms with recruiting difficulties are also more likely to assign a high importance on recruiting foreign skilled workers, however, in this case, to a larger degree for internationalized than for domestic firms. Results are available upon request.

\section{Additional file}

Additional file 1: Table SA.1. Descriptive statistics. Table SA.2: Training participation (year 2009), firms with <50 employees. Table SA.3: Training participation (year 2009), firms with 50+ employees.

Competing interests

The author declares that he has no competing interests.

\section{Acknowledgement}

The author is grateful to the Swiss State Secretariat for Education, Research, and Innovation (SERI) for the financing of this project, and thanks the Institute for Research on Labor and Employment (IRLE) at the University of California, Berkeley, for the hospitality while writing this article. Contact address: Dr. Samuel Muehlemann, University of Bern, Department of Economics, Centre for Research in Economics of Education, Schanzeneckstr. 1, CH-3001 Bern. E-Mail: samuel.muehlemann@vwi.unibe.ch.

Received: 17 October 2013 Accepted: 6 March 2014

Published: 15 May 2014

\section{References}

Backes-Gellner U, Tuor SN (2010) Avoiding labor shortages by employer signaling - on the importance of good work climate and labor relations. Ind Labor Relat Rev 63(2010):271-286. 2

BBT (2011) Berufsbildung - Ein Schweizer Standort- und Wettbewerbsfaktor. Studie bei multinationalen Unternehmen sowie Expertinnen und Experten in der Schweiz, in Deutschland und Grossbritannien. Bundesamt für Berufsbildung und Technologie (BBT), Bern

Beck N, Kabst R, Walgenbach P (2009) The cultural dependence of vocational training. J Int Bus Stud 40(8):1374-1395 Becker GS (1962) Investment in human capital: a theoretical analysis. J Polit Econ 70:9-49

Biavaschi C, Eichhorst W, Giulietti C, Kendzia MJ, Muravyev A, Pieters J, Rodriguez-Planas N, Schmidl R, Zimmermann KF (2012) Youth Unemployment and Vocational Training, IZA Discussion Papers No 6890. Institute for the Study of Labor (IZA), Bonn

Björkman I, Fey CF, Park HJ (2007) Institutional theory and MNC subsidiary HRM practices: evidence from a three-country study. J Int Bus Stud 38:430-446

Blossfeld H-P, Bos W, Lenzen D, Müller-Böling D, Prenzel M, Wössmann L (2008) Globalisierung und ihre Konsequenzen und Erfordernisse für die Berufsausbildung. In: Bildungsrisiken und -chancen im Globalisierungsprozess. Jahresgutachten 2008, vbw - Vereinigung der Bayerischen Wirtschaft e.V. (Hrsg.). VS Verlag für Sozialwissenschaften, Wiesbaden

Brockmann M, Clarke L, Winch C (2008) Knowledge, skills, competence: European divergences in Vocational Education and Training (VET) - the English, German and Dutch Cases. Oxf Rev Educ 34(5):547-567

Busemeyer MR, Trampusch C (ed) (2012) The Political Economy of Collective Skill Formation. Oxford University Press, Oxford 
Dickmann M (2003) Implementing German HRM abroad: desired, feasible, successful? Int J Hum Resour Man 14(2):265-283

Edwards T (2011) The Transfer of Employment Practices Across Borders in Multinational Companies. In: Harzing A-W, Pinnington AH (ed) International Human Resource Management. SAGE Publications Inc., Los Angeles, London, New Dehli, Singapore, Washington DC

Eichhorst W, Rodríguez-Planas N, Schmidl R, Zimmermann KF (2012) A Roadmap to Vocational Education and Training Systems Around the World. IZA Discussion Paper No. 7110. Institute for the Study of Labor (IZA), Bonn

Eriksson T (2010) Labour Market Outcomes of Internationalization - What Have We Learnt from Analyses of Microdata on Firms and Their Employees? In: Mardsen D, Rycx F (ed) Wage Structures, Employment Adjustments and Globalization. Palgrave Macmillan, Applied Econometrics Association Series

Gooderham P, Nordhaug O, Ringdal K (1998) When in Rome, Do They Do as the Romans? HRM Practices of US Subsidiaries in Europe. MIR: Management International Review, Vol. 38, Cross-Cultural and Comparative International Human Resource Management, 47-64. Springer, http://www.jstor.org/action/showPublication? journalCode=mirmanaintrev

Hall PA, Gingerich DW (2009) Varieties of capitalism and institutional complementarities in the political economy: an empirical analysis. Br J Polit Sci 39:449-482

Hall PA, Soskice D (ed) (2001) Varieties of capitalism. The Institutional Foundations of Comparative Advantage, Oxford

Holzer H (2012) Good workers for good jobs: improving education and workforce systems in the US. ZA J Labor Policy 2012 1(5):1-19

Kluike M (2012) Re-examining the host-country effect to include hybrid market economies: Is it sufficient to consider host- and home-country, and what role do the subsidy size and incorporation type play? Available at SSRN. SSRN, http://papers.ssrn.com/sol3/papers.cfm?abstract_id=2166846

Kostova T, Roth K, Dacin M (2008) Institutional Theory in the study of MNCs: a critique and new directions. Acad Manag Rev 33(4):994-1007

Lerman RI (2013) Skill Development in Middle Level Occupations: The Role of Apprenticeship Training. IZA Policy Papers No. 61. Institute for the Study of Labor (IZA), Bonn

Leuven E (2005) The economics of private sector training: a survey of the literature. J Econ Surv 19(1):91-111

Marsden D (1999) A Theory of Employment Systems. Oxford University Press, Oxford

MIS Trend (2008) Sophia 2008 - Die Schweizer und die Globalisierung

Morton J, Siebert WS (2001) Labor market regimes and worker recruitment and retention in the European Union: plant comparisons. Br J Ind Relat 39(4):505-528

Muehlemann S, Wolter SC (2007) Regional Effects on Employer Provided Training: Evidence from Apprenticeship Training in Switzerland. Journal for Labour Market Research (Zeitschrift für ArbeitsmarktForschung) 40(2+3):135-147

Muehlemann S, Wolter SC, Fuhrer M, Wüest A (2007a) Lehrlingsausbildung - ökonomisch betrachtet. Rüegger Verlag, Zürich/Chur

Muehlemann S, Schweri J, Winkelmann R, Wolter SC (2007b) An empirical analysis of the decision to train apprentices. LABOUR: Rev Labour Econ Industrial Relations 21(3):419-441

Pudelko M, Harzing A-W (2008) Country-of-origin, localization, or dominance effect? An empirical investigation of HRM practices in foreign subsidiaries. Hum Resour Manag 46(4):535-559

Rosenzweig P, Nohria N (1994) Influences on human resource management practices in multinational corporations. Journal of International Business Studies, Second Quarter, pp 229-251

Schmitt M, Sadowski D (2003) A cost-minimization approach to the international transfer of HRM/IR practices: Anglo-Saxon multinationals in the Federal Republic of Germany. Int J Hum Resour Man 14(3):409-430

Schweri J, Müller B (2008) Die Ausbildungsbereitschaft der Betriebe: Entwicklungen 1995 bis 2005. Bundesamt für Statistik, Neuchâtel

Strupler M, Wolter SC (2012) Die duale Lehre: eine Erfolgsgeschichte - auch für Betriebe. Ergebnisse der dritten Kosten-Nutzen-Erhebung der Lehrlingsausbildung aus der Sicht der Betriebe. Glarus/Chur, Rüegger Verlag

Wolter SC, Ryan P (2011) Apprenticeship. In: Hanushek EA, Machin S, Wössmann L (ed) Handbook of the Economics of Education, vol 3. Elsevier, Amsterdam, pp 522-576

Wolter SC, Muehlemann S, Schweri J (2006) Why some firms train apprentices and many others do not. Ger Econ Rev 7(3):249-264

doi:10.1186/s40461-014-0005-1

Cite this article as: Muehlemann: Training participation of internationalized firms: establishment-level evidence

for Switzerland. Empirical Research in Vocational Education and Training 2014 6:5.

\section{Submit your manuscript to a SpringerOpen ${ }^{\circ}$} journal and benefit from:

- Convenient online submission

- Rigorous peer review

- Immediate publication on acceptance

- Open access: articles freely available online

- High visibility within the field

- Retaining the copyright to your article

Submit your next manuscript at $\boldsymbol{\sim}$ springeropen.com 